\title{
Creatine kinase release in acute myocardial infarction: correlation with clinical, electrocardiographic, and pathological findings ${ }^{1}$
}

\author{
D. Mathey, W. Bleifeld, H. Buss, and P. Hanrath \\ From the Departments of Internal Medicine I and Pathology, Rheinisch-Westfälische Technische Hochschule, \\ Aachen, West Germany
}

Creatine kinase $(C K)$ release curves were analysed in 40 patients with acute myocardial infarction. Three groups could be identified. Group $A$ (duration of $C K$ release $<30$ hours) comprised 15 patients whose $C K$ release was completed within 22.8 hours. In these patients chest pain was noted on the first hospital day and necropsy in three showed a homogeneous myocardial infarction. Group $B$ (duration of $C K$ release $>30$ hours) comprised 16 patients who had a significantly longer $C K$ release time of 42.2 hours $(P \leqslant 0.05)$. Their chest pain persisted for two to three days and pathological examination in five patients showed a heterogeneous composition of the infarcted myocardium. Group $C$ comprised nine patients who had a second rise of serum $C K$. This was always associated with chest pain. It reflected an extension of the infarct which accounted on average for 24 per cent of the size of the final infarct.

We conclude that a $C K$ release of short duration indicated infarction without extension, $C K$ release of longer duration indicated a gradual extension of infarction, and a repeated $C K$ release resulted from a sudden extension of an infarct. According to these criteria an extension of the infarct occurred in 62 per cent of our patients.

Serial determinations of serum creatine kinase (CK) activity to assess the immediate and long-term prognosis were performed in all patients with acute myocardial infarction admitted to hospital during 1974. Unexpectedly the curves showed striking variability. In a few cases the curve was similar to that seen in dogs after experimental coronary occlusion, with a steep rise and an early discrete peak (Shell, Kjekshus, and Sobel, 1971). In most cases, however, significant deviations from this 'typical' shape were found. In order to find out if these deviations were related to the time-pattern of myocardial necrosis the measurements of $\mathrm{CK}$ activity were correlated with the clinical, electrocardiographic, and pathological findings.

\section{Patients and methods}

Forty patients with acute myocardial infarction were included in the study. The diagnosis of acute myocardial infarction was based on a typical history, the electro-

Received 21 April 1975.

${ }^{1}$ Supported by the Deutsche Forschungsgemeinshaft SFB rog. cardiogram, and serum enzyme changes. Initially serum CK activity in all patients was still within the normal range ( $<40 \mathrm{mU} / \mathrm{ml}$ ). Patients who had had intramuscular injections, direct current shock, or other possible cause of increase in serum $\mathrm{CK}$ activity were excluded from the study.

Blood for CK determinations was taken at one-, two-, or three-hourly intervals from the time of admission until CK activity had either returned to normal or, in patients who died, was decreasing. CK activity was measured with Boehringer CK activated test sets (Boehringer, Mannheim) at $25^{\circ} \mathrm{C}$, with an upper normal value of $40 \mathrm{mU} / \mathrm{ml}$ (Szasz, Busch, and Farohs, 1970). A r2-lead standard electrocardiogram was recorded on the day of admission and on the following three days. Daily ST segment changes were measured according to the criteria suggested by Reid et al. (1974) and expressed as a percentage of the initial ST segment height. Blood pressure, heart rate, arrhythmias, and clinical events were carefully monitored. The incidence and severity of recurrent chest pain were estimated by the patient's consumption of morphine or its derivatives.

A post-mortem examination was performed in 12 patients. For macroscopic observation the heart was cut into slices $0.5 \mathrm{~cm}$ thick, which were stained with NitroBT (Nachlas and Shnitka, 1963). As the result of a 


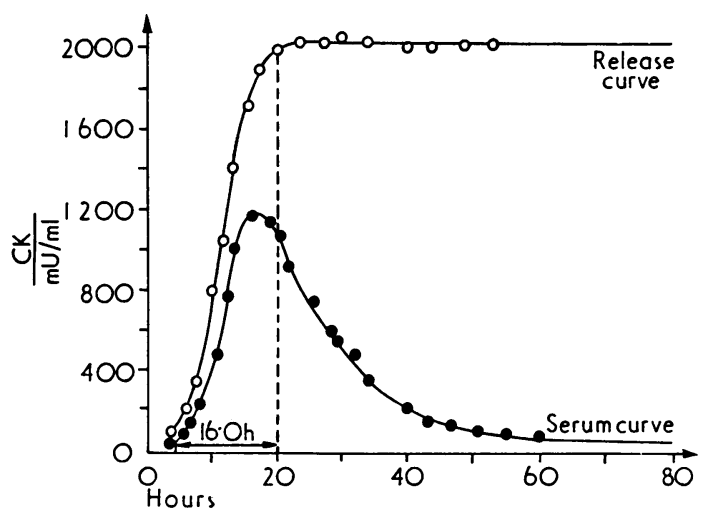

FIG. I CK serum and release curves in a representative case (Case 14) from group $A$. Serum $C K$ activity rises steeply, has early single peak, and a monoexponential decline thereafter. With the early decline of the serum curve the release curve flattens 16 hours after the serum curve exceeds $40 \mathrm{mU} / \mathrm{ml}$, indicating that no further release of myocardial $C K$ occurred. Post-mortem examination showed a large, homogeneous infarction, suggesting that the $C K$ release was from myocardial cells that had all died at the same time.
Nitro-BT-dehydrogenase reaction non-infarcted myocardium turned blue while the area of infarction remained unstained. Tissue from infarcted and noninfarcted myocardium was examined by light microscopy.

\section{Data analysis}

Serum CK activity after an acute myocardial infarction is mainly governed by two contrary mechanisms - release of CK from the myocardial infarct and elimination of $\mathrm{CK}$ from the serum. If there were no elimination of CK from the serum then CK activity would be the result only of CK release. A CK release curve may be calculated from the serum curve by adding to it the product of the area limited by the serum curve and the rate constant of elimination (Shell et al., 197r; Sobel et al., 1972; Mathey et al., 1974). In this study CK release curves were calculated by means of a computer programme, ${ }^{1}$ which was also utilized to plot serum and release curves as a function of time.

CK release is terminated when the release curve is at its maximum. The period between a serum CK activity of $40 \mathrm{mU} / \mathrm{ml}$ and the maximum of the release curve was defined as the CK release time (Fig. I). The maximal value of the release curve represents the total amount of $\mathrm{CK}$ that is released from the infarcted myocardium into $\mathrm{I} \mathrm{ml}$ of the distribution space. From this value the size of the infarct can be determined (Shell et al., 197I;

${ }^{1}$ P. Mayoipoulos Dept. of Documentation and Statistics, Rhein.-Westf. Techn. Hochschule, Aachen, Goethestr 27/29.

TABLE I Clinical details of 15 patients in group $A$

\begin{tabular}{|c|c|c|c|c|c|c|c|}
\hline Case No. & Age & $\begin{array}{l}\text { Site of } \\
\text { infarct }\end{array}$ & $\begin{array}{l}\text { Preinfarction } \\
\text { angina }\end{array}$ & $\begin{array}{l}\text { Interval between } \\
\text { onset of pain and } \\
\text { CK of } 40 \mathrm{mU} / \mathrm{ml} \\
(h)\end{array}$ & $\begin{array}{l}\text { CK release time } \\
\text { (h) }\end{array}$ & $\begin{array}{l}\text { Infarct size } \\
(g)\end{array}$ & $\begin{array}{l}\text { Rate constant } \\
\text { of CK } \\
\text { elimination } \\
\left(h^{-1}\right)\end{array}$ \\
\hline $\mathbf{I}$ & 75 & A & - & $?$ & 16.4 & 29 & 0.06 \\
\hline 2 & 45 & I & - & 4.5 & 27.4 & 50 & 0.06 \\
\hline 3 & 53 & I & + & 3.5 & 26.0 & 83 & 0.07 \\
\hline 4 & 59 & A & - & 3.8 & 28.0 & 91 & 0.07 \\
\hline 5 & 46 & I & - & 6.5 & 25.0 & 27 & 0.07 \\
\hline 6 & 56 & A & - & 5.0 & 21.8 & 27 & - \\
\hline 7 & 75 & & + & $3 \cdot 3$ & 20.0 & 23 & 0.06 \\
\hline 8 & 59 & I & - & 4.2 & 23.0 & 27 & 0.06 \\
\hline 9 & 58 & I & + & 3.5 & 27.0 & 78 & 0.06 \\
\hline Io & 65 & I & + & 4.0 & 29.0 & 37 & 0.07 \\
\hline I I & 67 & A & - & 3.5 & 17.0 & 13 & 0.12 \\
\hline 12 & 67 & A & - & 1.5 & 18.2 & 76 & - \\
\hline 13 & 59 & $\mathbf{I}, \mathbf{A}$ & - & 1.2 & 27.0 & 184 & - \\
\hline 14 & 79 & I & + & 6.0 & 16.0 & 63 & 0.36 \\
\hline 15 & 61 & A & - & 2.8 & 20.0 & 86 & 0.06 \\
\hline \multicolumn{4}{|c|}{ Mean \pm SEM } & $3.8 \pm 0.5^{\star}$ & $22.8 \pm 5.5^{\star}$ & $59.6 \pm$ II.2† & $0.07 \pm 0.02$ \\
\hline
\end{tabular}

* Significant difference between groups A and B.

† Significant difference between groups $A$ and $C$.

$\mathbf{I}=$ Infarct of inferior wall; $\mathbf{A}=$ Infarct of anterior wall. 
Sobel et al., 1972) with an accuracy of $\pm 10 \mathrm{~g}$ (Bleifeld et al., 1974) using the formula:

Infarct size $(\mathrm{g})=\max$. value rel. curve $(\mathrm{U} / \mathrm{ml}) \times$ body

$$
\text { weight }(\mathrm{g}) \times 0.0005\left(\frac{\mathrm{ml}}{\mathrm{U}}\right) \text {. }
$$

The constant used in this equation is derived as follows:

$\frac{0.074}{0.3 \times 500}=0.0005$ where 0.074 represents the ratio of the CK distribution volume on the whole body weight (Bleifeld et al., 1974); 0.3 is the proportion of depleted myocardial CK appearing in the serum; 500 is the amount of $\mathrm{CK}(\mathrm{U} / \mathrm{ml})$ depleted from myocardium undergoing necrosis (B.E. Sobel, r974, personal communication).

The rate constant of $\mathrm{CK}$ elimination was obtained from the slope of the terminal portion of the serum curve if the latter was plotted semi-logarithmically.

\section{Results}

Three groups of patients could be identified from the duration of CK release. Group A consisted of 15 patients with a $\mathrm{CK}$ release time of less than 30 hours, group B of 16 patients with a $\mathrm{CK}$ release time of more than 30 hours, and group $C$ of nine patients who had a further release of CK. More detailed analysis of the three groups showed that they were largely homogeneous in relation to clinical and pathological findings. The arbitrary 30 hours' limit between groups A and B was chosen because it is compatible with the experimental finding that the minimum residual $\mathrm{CK}$ activity in

\begin{tabular}{lllll} 
ST segment change (\%) & \multicolumn{3}{c}{ Chest pain hospital day } & Died \\
Day $I-2$ & Day 2-3 & $I_{2}$ & 3
\end{tabular}

\begin{tabular}{llllll}
\hline-55 & -35 & + & - & - & - \\
-45 & -5 & + & - & - & - \\
-71 & 0 & + & - & - & - \\
-59 & -35 & + & + & - & - \\
$?$ & $?$ & + & - & - & - \\
-24 & -40 & + & - & - & - \\
$?$ & $?$ & + & - & - & - \\
- & - & + & - & - & - \\
- & - & + & - & - & - \\
-44 & -12 & + & - & - \\
- & - & + & - & - \\
venticular pacing & + & - & - \\
-74 & $?$ & + & - & - \\
-52 & -13 & + & - & - \\
-52 & -13 & + & -
\end{tabular}

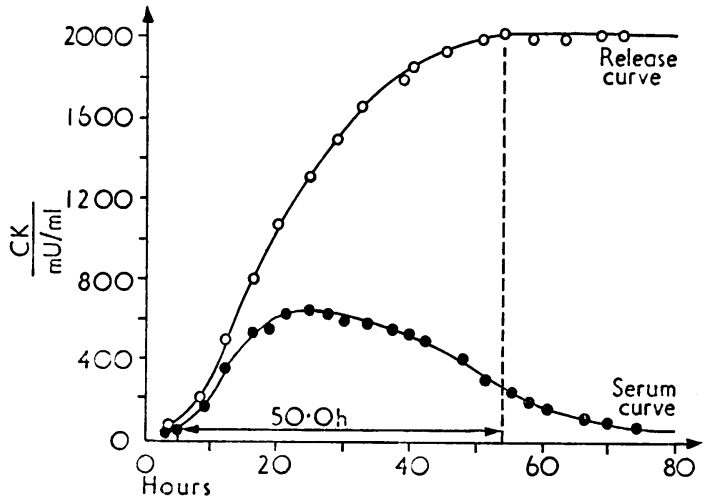

FIG. $2 C K$ serum and release curves in the representative case (Case 14) from group $B$. The serum $C K$ curve rises slowly and the $C K$ release time is prolonged to 50 hours. Post-mortem examination showed a laminar type of infarction.

infarcted myocardium occurs 24 hours after coronary occlusion (Kjekshus and Sobel, 1970). Since CK enters the circulation after a mean delay of four hours CK release from a uniform necrosis should be completed within 30 hours.

\section{Group A}

The course of the serum CK curve in these 15 (38\% of the whole series) patients, whose clinical

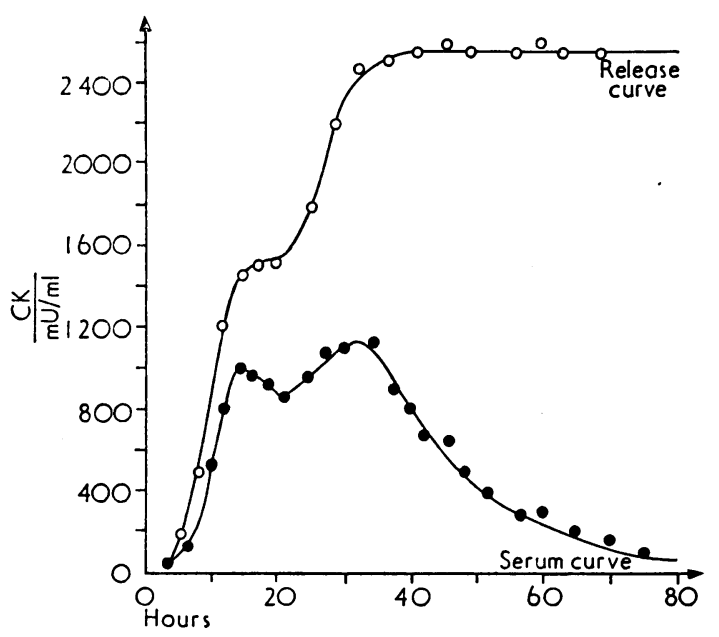

FIG. 3 Changes in CK serum and release curves in a representative case (Case 8) in group C. 60 hours after onset of pain there is a second peak in the still raised serum CK activity. This was associated with severe chest pain, and a following rise in the release curve reflects an increase of the infarction. 
TABLE 2 Post-mortem findings in 3 patients in group $A$

\begin{tabular}{lll}
\hline Case No.* & Macroscopical findings & Microscopical findings \\
\hline I2 & $\begin{array}{l}\text { Full thickness infarct of IV septum and LV anterior } \\
\text { wall } \\
\text { Extensive infarct of entire thickness of IV septum } \\
\text { and LV inferior wall; laminar necrosis of LV } \\
\text { anterior wall } \\
\text { Large infarct of IV septum and LV inferior wall }\end{array}$ & $\begin{array}{l}\text { Homogeneous necrosis with peripheral neutrophilic } \\
\text { infiltration } \\
\text { Extensive homogeneous necrosis }\end{array}$ \\
I4 & $\begin{array}{c}\text { Homogeneous necrosis with neutrophilic infiltration } \\
\text { and focal haemorrhages }\end{array}$
\end{tabular}

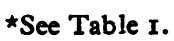

TABLE 3 Clinical details of 16 patients in group $B$

\begin{tabular}{|c|c|c|c|c|c|c|c|}
\hline Case No. & Age & $\begin{array}{l}\text { Site of } \\
\text { infarct }\end{array}$ & $\begin{array}{l}\text { Preinfarction } \\
\text { angina }\end{array}$ & $\begin{array}{l}\text { Interval between } \\
\text { onset of pain and } \\
C K \text { of } 40 \mathrm{mU} / \mathrm{ml} \\
\text { (h) }\end{array}$ & $\begin{array}{l}\text { CK release time } \\
\text { (h) }\end{array}$ & $\begin{array}{l}\text { Infarct size } \\
(g)\end{array}$ & $\begin{array}{l}\text { Rate constant } \\
\text { of CK } \\
\text { elimination } \\
\left(h^{-1}\right)\end{array}$ \\
\hline $\mathbf{I}$ & 35 & I & $?$ & $?$ & 44.4 & 55 & 0.07 \\
\hline 2 & 57 & I & + & 45 & 43.0 & 85 & 0.04 \\
\hline 3 & 52 & I & + & $?$ & 40.0 & 68 & 0.07 \\
\hline 4 & 69 & A & + & 5.0 & 30.4 & 106 & 0.05 \\
\hline 5 & 65 & A & - & 3.0 & 59.8 & 78 & 0.06 \\
\hline 6 & 60 & A & + & 4.0 & 40.0 & 43 & 0.07 \\
\hline 7 & 52 & A & + & 10.0 & 39.0 & 40 & 0.06 \\
\hline 8 & 62 & A & + & 9.0 & $4 \mathrm{I} .4$ & 60 & 0.06 \\
\hline 9 & 47 & I & - & 5.0 & 36.0 & 54 & 007 \\
\hline 10 & 30 & I & - & 4.3 & 31.0 & 93 & 0.06 \\
\hline II & 62 & I & - & 2.0 & 55.0 & 152 & 0.06 \\
\hline 12 & 69 & A & + & 5.0 & 33.2 & 21 & 0.06 \\
\hline 13 & 67 & I & + & 10.5 & 41.4 & 36 & 0.08 \\
\hline 14 & 72 & A & + & $?$ & 50.0 & 59 & 0.07 \\
\hline 15 & 73 & A & + & 9.0 & 56.0 & 100 & 0.07 \\
\hline 16 & 64 & I & + & 3.8 & 34.5 & 90 & 0.06 \\
\hline \multicolumn{4}{|c|}{ Mean \pm SEM } & $5.8^{\star} \pm 0.8$ & $42.2 † \pm 2.2$ & $71.3^{\star} \pm 8.2$ & $0.06 \pm 0.009$ \\
\hline
\end{tabular}

* Significant difference between groups A and B.

+ Significant difference between groups $B$ and $C$.

$I=$ Infarct of inferior wall; $A=$ Infarct of anterior wall.

TABLE 4 Post-mortem findings in 5 patients in group $B$

\begin{tabular}{lll}
\hline Case No.* & Macroscopical findings & Microscopical findings \\
\hline I2 & $\begin{array}{l}\text { Laminar and in some parts disseminated necrosis of } \\
\text { IV septum and LV anterior wall }\end{array}$ & $\begin{array}{c}\text { Old fibrous scars; early necrosis of surrounding } \\
\text { muscle fibre bundles; granulation tissue, estimated } \\
\text { age about I2 days }\end{array}$ \\
I3 & Disseminated necrosis in old scar of LV inferior wall & $\begin{array}{c}\text { Small areas of early necrosis surrounded by living } \\
\text { injured and scarred tissue } \\
\text { Necrotic muscle fibres separated by granulation } \\
\text { tissue of different age (Fig. 3) }\end{array}$ \\
I5 & $\begin{array}{l}\text { Laminar necrosis of subendocardial layers of } \mathrm{LV} \\
\text { anterior wall }\end{array}$ & $\begin{array}{c}\text { Areas of early necrosis without leucocytic infiltration } \\
\text { cells; surrounded by granulation tissue, scars, and } \\
\text { partially removed necrotic muscle; large area } \\
\text { with fragmentation and swelling of the } \\
\text { sarcoplasma of the heart muscle cells }\end{array}$ \\
I6 & $\begin{array}{c}\text { Early focal necrosis separated by living muscle } \\
\text { fibres; beginning neutrophilic infiltration }\end{array}$
\end{tabular}

* See Table 3 . 
data are summarized in Table $I$, showed a steep rise, an early peak, and a mono-exponential decline thereafter. According to the early fall of the serum curve $\mathrm{CK}$ release was completed after a mean of $\mathbf{2 2 . 8}$ hours. A representative example of this type of CK release is shown in Fig. I. Of the 15 patients in the group 14 complained of chest pain only on their first hospital day. The onset was sudden and unexpected in 10 of the 15 patients with a mean delay of 3.8 hours before the serum CK activity was

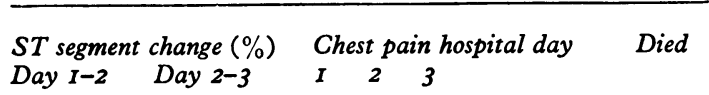

\begin{tabular}{|c|c|c|c|c|c|c|}
\hline+30 & -5 & + & - & - & & - \\
\hline-20 & 0 & + & + & - & & - \\
\hline$?$ & $?$ & + & + & + & & - \\
\hline$?$ & $?$ & + & + & - & & - \\
\hline-65 & + Io & + & - & + & & - \\
\hline-33 & -10 & + & + & - & & - \\
\hline+38 & +9 & + & + & + & & - \\
\hline-44 & -16 & + & + & - & & - \\
\hline-74 & +6 & + & + & - & & - \\
\hline-65 & -20 & + & + & - & & - \\
\hline-31 & -9 & + & + & - & & - \\
\hline-38 & -27 & + & - & - & & + \\
\hline$?$ & $?$ & + & - & - & & + \\
\hline$?$ & $?$ & - & - & - & & + \\
\hline+3 & 0 & + & + & + & (pericarditis) & + \\
\hline-40 & $?$ & + & + & - & & + \\
\hline
\end{tabular}

raised to $40 \mathrm{mU} / \mathrm{ml}$. In three patients who died necropsy showed a homogeneous, sharply demarcated necrosis (Table 2).

\section{Group B}

In the $16(40 \%$ of the whole series) patients in group $B$ the mean CK release time was prolonged to 42.2 hours, which was nearly twice that of group $A$ $(P<0.05)$. In contrast to group $A$, the serum $C K$ curve showed a slow rise and a flat single peak (Fig. 2). Eleven patients complained of chest pain persisting for the first two to three hospital days. The onset of severe chest pain was preceded by preinfarction angina ( $\mathrm{Yu}, 1973)$ in II patients (Table 3). The delay between the onset of severe chest pain and the time when serum CK activity exceeded $40 \mathrm{mU} / \mathrm{ml}$ averaged 5.8 hours, which was significantly more than in group $A(P<0.05)$. The infarcts in patients in group B were of heterogeneous composition. Three showed a laminar or disseminated necrosis and in one case (Case 16) there was a large, non-uniform infarction. Histological examination in five cases revealed an infarction area composed of dead, viable, and variously injured tissue. Dead tissue was found in different stages of repair (Table 4). Daily ST segment changes in the standard electrocardiogram did not differ significantly between group $\mathbf{A}$ and $\mathbf{B}$.

\section{Group C}

In the 9 patients $(22 \%$ of the whole series) in group $\mathrm{C}$ (Table 5) a second or third peak in a persistently raised serum CK activity was seen $20-40$ hours after the onset of chest pain. As can be seen (Fig. 3), the second peak of the serum CK curve was followed by a corresponding rise in the release curve, reflecting an increase in the infarct size. Including all peaks of the serum curve the mean final infarct size in cases in group $\mathrm{C}$ was $89 \mathrm{~g}$, of which $22 \mathrm{~g}$ - that is, 24 per cent - may be attributed to the second peak in the serum CK curve. In six of the cases the standard electrocardiogram failed to indicate the extension of the infarct. In two patients the second peak of serum CK activity was accompanied by a rise in previously isoelectric ST segments. This was found in one patient (Case 4) when rapid atrial fibrillation occurred. Five of the patients in group $\mathrm{C}$ died, four of acute left heart failure and one of cardiac rupture. The post-mortem examination (Table 6) of the hearts showed an extensive, homogeneous necrosis in three patients similar to that seen in the patients in group A. In one patient (Case 8) there was evidence of repeated infarction.

\section{Discussion}

CK activity in infarcted rabbit myocardium was found to be at a minimum 24 hours after the coronary occlusion (Kjekshus and Sobel, 1970). Within this period CK is released from the infarcted myocardium and enters the serum. This process is called CK release and its duration was defined by us as CK release time. In the present study the CK release time ranged from 16 to 60 hours. The mean short CK release time of 22.8 hours in the patients in group A corresponds well with the duration of $\mathrm{CK}$ release found in the animal experiments referred to above. This finding, the short duration of chest pain, and the homogeneous composition of the infarction found at necropsy in three patients support the idea that, as in infarction after experimental acute coronary occlusion, all the 
TABLE 5 Clinical details of 9 patients in group $C$

\begin{tabular}{|c|c|c|c|c|c|c|c|c|c|c|}
\hline $\begin{array}{l}\text { Case } \\
\text { No. }\end{array}$ & Age & $\begin{array}{l}\text { Site of } \\
\text { infarct }\end{array}$ & $\begin{array}{l}\text { Preinfarction } \\
\text { angina }\end{array}$ & $\begin{array}{l}\text { Interval between } \\
\text { onset of pain and } \\
C K \text { of } 40 \mathrm{mU} / \mathrm{ml} \\
(h)\end{array}$ & $\begin{array}{l}\text { CK release } t \\
\text { First }\end{array}$ & $\begin{array}{l}\text { time }(h) \\
\text { Second }\end{array}$ & $\begin{array}{l}\text { Infarct } \\
\text { First }\end{array}$ & $\begin{array}{l}(g) \\
\text { Second }\end{array}$ & Third & Final \\
\hline I & $7 I$ & I & $?$ & $?$ & 25.6 & 48.0 & 59 & 5 & - & 64 \\
\hline 2 & 42 & $A$ & - & 5.3 & 27.0 & - & 82 & 28 & - & 110 \\
\hline 3 & 68 & A & - & $?$ & - & 470 & $6 j$ & 20 & - & 85 \\
\hline 4 & 59 & I & - & 42 & 345 & 47.0 & 43 & 3 & - & 46 \\
\hline 5 & 70 & A & + & 1.5 & 12.0 & 400 & 40 & 62 & 20 & 122 \\
\hline 6 & 53 & I & + & 4.3 & 24.0 & 440 & IOI & 11 & - & 112 \\
\hline 7 & 64 & I & + & 5.5 & 320 & 410 & 60 & 3.7 & - & 74 \\
\hline 8 & 72 & $A$ & - & ? & 20.0 & 40.0 & 59 & 41 & - & ס0 \\
\hline 9 & 66 & I & + & 5.0 & - & 300 & 51 & II & 28 & 90 \\
\hline
\end{tabular}

$\star$ Pericarditis.

† Significant difference between groups B and C.

¥ Significant difference between groups $A$ and $C$.

$\mathrm{I}=$ Infarct of inferior wall; $A=$ Infarct of anterior wall.

myocardial necrosis developed at the same time without further extension of the infarct. As the increase in serum CK activity is usually noted four hours after infarction has occurred it may be concluded from the time interval of 3.8 hours between the onset of chest pain and a serum CK activity of $40 \mathrm{mU} / \mathrm{ml}$ that in group A chest pain and the onset of infarction generally coincided.

Patients in group B had a mean CK release time of 42.2 hours, which was significantly longer than that of patients in group A. Several factors must be considered in the interpretation of this difference in $\mathrm{CK}$ release time. The infarct size and the rate of CK elimination can be excluded, because there was no significant difference between group $A$ and $B$ in these two values. A delay of $\mathrm{CK}$ release or a grad- ual extension of the infarct could account for the prolonged CK release period in group B. Though a delay in CK release cannot be definitely rejected, the persistence of severe chest pain during two to three hospital days is more consistent with an extension of infarction. This is supported by the pathological studies. They showed typical findings of incomplete infarction, which is characterized by a mixed composition of dead, living, and variously injured tissue (Wartman, 1963). Dead tissue was found in different phases of repair, indicating that cellular damage had occurred over a period. The myocardial cells that die later are supposed to be the source of the CK that appears later, thus resulting in a prolonged $\mathrm{CK}$ release time. As a further difference between groups $\mathrm{A}$ and $\mathrm{B}$ the interval

TABLE 6 Post-mortem findings in 4 of the 5 patients in group $C$ who died

\begin{tabular}{lll}
\hline Case No.* & Macroscopical findings & Microscopical findings \\
\hline 5 & $\begin{array}{l}\text { Full thickness infarct of IV septum and LV anterior } \\
\text { wall }\end{array}$ & $\begin{array}{c}\text { Diffuse, dense neutrophilic infiltrate in association } \\
\text { with necrotic muscle cells of which nuclei had } \\
\text { completely disappeared. Focal necrosis with } \\
\text { pyknotic nuclei and less dense infiltration }\end{array}$ \\
7 & $\begin{array}{l}\text { Full thickness infarct of } \mathrm{LV} \text { inferior wall; sub- } \\
\text { endocardial laminar necrosis of } \mathrm{LV} \text { anterior wall } \\
\text { Large infarct involving more than half of thickness } \\
\text { of } \mathrm{LV} \text { anterior wall; laminar necrosis of the inner } \\
\text { layers at base }\end{array}$ & $\begin{array}{l}\text { Early homogeneous necrosis with small foci of } \\
\text { necrotic tissue partially removed by dense } \\
\text { granulation tissue }\end{array}$ \\
$\begin{array}{l}\text { Full thickness necrosis of } \mathrm{LV} \text { inferior wall and IV } \\
\text { septum; second separate infarct area is seen in LV } \\
\text { lateral wall }\end{array}$ & $\begin{array}{c}\text { Early homogeneous necrosis; beginning leucocytic } \\
\text { infiltration }\end{array}$ \\
\hline
\end{tabular}

\footnotetext{
$\star$ See Table 5 .
} 


\begin{tabular}{|c|c|c|c|c|c|c|c|}
\hline \multirow{2}{*}{$\begin{array}{l}\text { Rate constant of } \\
\text { CK elimination } \\
\left(h^{-1}\right)\end{array}$} & \multicolumn{2}{|c|}{ ST segment change $(\%)$} & \multirow{2}{*}{$\begin{array}{l}\text { Infarct extension } \\
\text { detected by ECG }\end{array}$} & \multicolumn{3}{|c|}{ Chest pain hospital day } & \multirow[t]{2}{*}{ Died } \\
\hline & Day $I-2$ & Day 2-3 & & $I$ & 2 & 3 & \\
\hline 0.05 & -39 & -29 & + & + & + & - & - \\
\hline 0.07 & -20 & +8 & - & + & + & $+\star *$ & - \\
\hline 0.07 & -16 & $-2 I$ & - & + & + & - & - \\
\hline 0.06 & -14 & -24 & + & + & + & - & - \\
\hline - & -33 & -5 & + & + & + & + & + \\
\hline 0.05 & -79 & +26 & - & + & + & - & + \\
\hline- & -82 & -9 & - & + & + & - & + \\
\hline $0 . c 6$ & $-6 I$ & -25 & - & + & + & - & + \\
\hline- & -25 & -60 & - & + & + & + & + \\
\hline $0.06 \pm 0.009$ & $-41 \pm 8.9$ & $-15.4+13$ & & & & & \\
\hline
\end{tabular}

from the onset of chest pain until the rise of serum $\mathrm{CK}$ activity to $40 \mathrm{mU} / \mathrm{ml}$ was significantly longer in group $B$, suggesting that the beginning of severe chest pain preceded the onset of infarction.

Further rises in serum CK activity associated with severe chest pain were seen in 22 per cent of the patients (group C). In experimental infarction it has been shown that a second rise in serum CK activity represented a sudden extension of the infarct (Shell et al., 197I). It is reasonable to assume that this was also the case in the patients in group C. An extension of infarction accounted for 24 per cent of the final infarct size and may be regarded as a major factor in the poor prognosis in this group.

In conclusion, analysis of $\mathrm{CK}$ serum and release curves showed three modes of CK release: short, long, and repeated release. Comparison with clinical and pathological data showed that these three modes probably reflect a different mechanism of infarct development. CK release of short duration occurs in an infarction without extension, a long duration of $\mathrm{CK}$ release occurs in patients with gradual infarct extension, and repeated $\mathrm{CK}$ release occurs with sudden infarct extension. According to these criteria there was an extension of infarct in 78 per cent of our patients. This high incidence again emphasizes the potential value of treatment designed to limit the final infarct size (Reid et al., 1974; Maroko, 1974). Serial CK determinations may be an appropriate way of evaluating the effectiveness of such a therapy. Isoenzyme estimations may be of more value for this purpose, but the accuracy of the methods of measuring them is still a matter of controversy.

\section{References}

Bleifeld, W., Mathey, D., Hanrath, P., Buss, H., and Effert, S. (1974). Serienuntersuchungen der Kreatinphosphokinase zur intravitalen Bestimmung der Infarktgröße. Verhandlungen der Deutschen Gesellshaft für Kreislaufforschung, 40, 449.

Kjekshus, J. K., and Sobel, B. E. (1970). Depressed myocardial creatine phosphokinase activity following experimental myocardial infarction in rabbit. Circulation Research, 27, 403.

Maroko, P. R. (1974). Assessing myocardial damage in acute infarcts. New England fournal of Medicine, 290, 158.

Mathey, D., Bleifeld, W., Hanrath, P., and Effert, S. (1974). Attempt to quantitate relation between cardiac function and infarct size in acute myocardial infarction. British Heart fournal, 36, 27 I.

Nachlas, M. M., and Shnitka, T. K. (1963). Macroscopic identification of early myocardial infarcts by alterations in dehydrogenase activity. American fournal of Pathology, 42, 379.

Reid, P. R., Taylor, D. R., Kelly, D. T., Weisfeldt, M. L., Humphries, J. N., Ross, R. S., and Pitt, B. (1974). Myocardial-infarct extension detected by precordial ST-segment mapping. New England fournal of Medicine, 290, 123.

Shell, W. E., Kjekshus, J. K., and Sobel, B. E. (1971). Quantitative assessment of the extent of myocardial infarction in the conscious dog by means of analysis of serial changes in serum creatine phosphokinase activity. fournal of Clinical Investigation, 50, 2614.

Sobel, B. E., Bresnahan, G. F., Shell, W. E., and Yoder, R. D. (1972). Estimation of infarct size in man and its relation to prognosis. Circulation, 46, 640.

Szasz, G., Busch, E. W., and Farohs, H. B. (1970). SerumKreatinkinase. I. Methodische Erfahrungen und Normal- 
werte mit einem neuen handelsüblichen Test. Deutsche medizinische Wochenschrift, 95, 829.

Wartman, W. B. (1963). Definition of myocardial infarction. In The Etiology of Myocardial Infarction, pp. I15-134. Ed. by T. N. James and J. W. Keyes. Churchill, London.

Yu, P. N. (1973). Preinfarction syndrome. In Myocardial
Infarction, pp. 210-214. Ed. by E. Corday and H. J. C. Swan. Williams and Wilkins, Baltimore.

Requests for reprints to Professor W. Bleifeld, Abteilung Innere Medizin I/RWTH, Goethestrasse 27/29, D-5100 Aachen, W. Germany. 